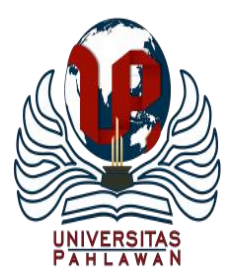

\title{
JURNALBASICEDU
}

Volume 5 Nomor 5Tahun 2021 Halaman 3158 - 3166

Research \&Learningin Elementary Education https://jbasic.org/index.php/basicedu

\section{Analisis Kesulitan Belajar Matematika Secara Daring Bagi Siswa Sekolah Dasar}

\author{
Zuraida Nisaul Alfiyah ${ }^{1 凶}$, Sri Hartatik ${ }^{2}$, Nafiah $^{3}$, Sunanto ${ }^{4}$
}

Universitas Nahdlatul Ulama Surabaya, Indonesia ${ }^{1,2,3,4}$

E-mail: zuraidanisaul@gamail.com ${ }^{1}$, titax@unusa.ac.id ${ }^{2}$, nefi_23@unusa.ac.id ${ }^{3}$, sunanto@unusa.ac.id $^{4}$

\begin{abstract}
Abstrak
Latar Belakang penelitian ini dengan adanya permasalahan siswa kelas $\mathrm{V}$ yang mengalami kesulitan belajar matematika. Oleh karena itu penelitian ini bertujuan untuk menganalisis kesulitan siswa belajar matematika secara daring. Metode penelitian data yang di pakai penelitian diperoleh dari wawancara dan dokumentasi langsung siswa sekolah dasar, dengan analisis pendekatan jenis Deskriptif kualitatif dua jenis di antaranya wawancara dan dokumentasi, berjumalah 25 siswa. Kemudian data dikumpulkan sehinga menjelaskan temuan dan didapat kesimpulan akhir. Hasil penelitian ini berdasarkan ke dua jenis yang dilakukan di penelitian ini, terdapat temuan kesimpulan akhir berada pada kategori tergolong masih kurang. Simpulan Secara umum, penelitian yang dilakukan untuk menganalisis analisis kesulitan belajar matematika secara daring bagi siswa membuktikan bahwa ke dua jenis yang dilakukan di penelitian ini, terdapat temuan kesimpulan akhir berada pada kategori tergolong masih kurang dan adanya keterbatasan media dan jaringan internet.
\end{abstract}

Kata Kunci: kesulitan belajar, faktor yang menyebabkan kesulitan belajar, matematika secara daring.

\section{Abstract}

The background of this research is the problem of fifth grade students who have difficulty learning mathematics. Therefore, this study aims to analyze the difficulties of students learning mathematics boldly. The research method used was data obtained from interviews and direct documentation of elementary school students, with a qualitative descriptive type approach analysis of two types including interviews and documentation, totaling 25 students. Then the data is collected so as to explain the findings and the final conclusions obtained. The results of this study based on the two types carried out in this study, it was found that the final findings were in the category classified as still lacking. In general, the research conducted to analyze the difficulty of learning mathematics boldly for students to prove that the two types carried out in this study, there were findings that the final conclusion was in the category of still lacking and the limitations of media and internet network.

Keywords:learning difficulties, factors that cause learning difficulties, online mathematics.

Copyright (c) 2021 Zuraida Nisaul Alfiyah, Sri Hartatik, Nafiah, Sunanto

$\triangle$ Corresponding author :

Email : zuraidanisaul@gamail.com

DOI $\quad:$ https://doi.org/10.31004/basicedu.v5i5.1297

ISSN 2580-3735 (Media Cetak)

ISSN 2580-1147 (Media Online) 
3159 Analisis Kesulitan Belajar Matematika Secara Daring Bagi Siswa Sekolah Dasar - Zuraida Nisaul Alfiyah, Sri Hartatik, Nafiah, Sunanto

DOI: https://doi.org/10.31004/basicedu.v5i5.1297

\section{PENDAHULUAN}

Banyak siswa sekolah dasar yang menganggap matematika sebagai pembelajaran yang paling sulit dan rumit (Fauzy \& Nurfauziah, 2021). Dengan demikian, siswa harus dapat memahami pembelajaran matematika karena matematika merupakan sarana untuk memecahkan masalah sehari-hari seperti halnya membaca dan menulis. Kesulitan belajar matematika dalam memahami konsep harus diberikan solusi sedini mungkin, kalau tidak siswa akan menghadapi banyak masalah kedepannya karena hampir semua bidang studi membutuhkan matematika yang tepat. Menurut Wahyudi, matematika merupakan ilmu yang mempelajari tentang sistem yang abstrak berupa bentuk elemen-elemen yang abstrak juga serta elemen-elemen itu tidak dapat diilustrsikan pada pola yang konkrit (Annurwanda \& Friantini, 2019).

Pembelajaran matematika perlu adanya rancangan sehingga dapat mengakomodasikan berbagai macam karakteristik siswa (Rini et al., 2020). Siswa yang mengalami kesulitan belajar dapat menimbulkan beberapa gejala kesulitan belajar yang bervariasi (Mufarizuddin, 2018). Hambatan yang membuat siswa kurang memahami konsep matematika yang diserap oleh siswa tersebut biasanya disebut dengan kesulitan belajar (Jamaris, 2014). Faktor yang berpengaruh pada kesulitan belajar sulit untuk meresmikan karena faktor tersebut bersifat bertautan (Asriyanti \& Purwati, 2020). Kesulitan belajar dapat dialami oleh siswa kelompok kemampuan tinggi, sedang, dan rendah. Misalnya guru memulai dari bagian yang konkrit bahwa setiap siswa dapat menunjukan banyaknya permen selanjutnya siswa secara abstrak akan mengenal suatu simbol bilangan (Suwarto, 2018). Menurut Widdiharto kesulitan belajar merupakan kurang berhasilnya siswa dalam memahami dan menguasai konsep, prinsip, atau struktur penyelesaian masalah pada materi tersebut (Waskitoningtyas, 2016).

Pada kondisi saat ini, dunia dikejutkan dengan mewabahnya virus COVID 19. Wabah ini disebabkan oleh Severe Acute Respiratory Syndrome Coronavirus-2 (SARSCoV-2) (Susilo et al., 2020).Hampir semua berdampak pada semua negara oleh wabah yang awalnya ditemukan di kota Wuhan ini (Annur \& Hermansyah, 2020). Dalam hal ini sangat berdampak pada bidang pendidikan. Mengenai kebijakan penyelenggaraan pendidikan selama masa pandemi COVID 19 yakni adanya pembelajaran dari rumah yang digunakan guru dengan siswa tanpa bertatap muka secara langsung. Penggunaan media yang tepat diperlukan agar dapat memberikan akses pembelajaran yang efektif bagi peserta didik selama masa darurat COVID19(Baety \& Munandar, 2021). Saat belajar di rumah memfokuskan pendidikan pada kehidupan nyata antara lain mengenai pandemi Covid-19(Dewi, 2020). Kemajuan dalam bidang teknologi informasi dan komunikasi saat ini membawa berbagai macam perubahan dalam kehidupan manusia (Bilfaqih, 2015). Namun, dalam kondisi saat ini diwajibkan seluruh siswa untuk belajar daring. Pelaksanaan pembelajaran daring menggunkan teknologi sebagai sarana serta internet sebagai sistem dalam pembelajaran jarak jauh (Fitriyani et al., 2020). Sistem belajar mengajar diganti dengan pembelajaran daring supaya proses pembelajaran tetap berjalan seperti biasanya (Sintema, 2020). Pembelajaran daring merupakan pembelajaran yang dilakukan melalui jaringan web. Setiap pembelajaran menyajikan materi dalam bentuk rekaman, dengan memberikan tugastugas harian sampai mingguan yang harus dikerjakan dengan batas waktu pengerjaan yang telah ditentukan dan bermacam-macam sistem penilaian (Bilfaqih, 2012).

Pembelajaran yang diterapkan pada pembelajaran daring salah satunya yakni pembelajaran matematika. Menurut Bruner belajar matematika merupakan belajar tentang konsep-konsep matematika yang ada di dalam sebuah materi yang akan dipelajari serta mencari suatu hubungan konsep dengan struktur matematika (Yusmin, 2017). Pada pembelajaran matematika siswa dapat memiliki kesempatan untuk mengembangkan dan meningkatkan kemampuan berpikir melalui penyelesaian masalah yang beragam. Namun kenyataannya, kemampuan pemecahan masalah matematika siswa Indonesia masih tergolong rendah. Siswa kesulitan dalam memahami konsep, kesulitan dalam menggunakan prinsip matematika, kesulitan dalam menyelesaikan soal yang memiliki masalah verbal sehingga dalam merencanakan dan menerapkan penyelesaiannya mendapat 
hasil yang kurang memuaskan. Akibatnya kemampuan pemecahan masalah siswa menjadi kurang berkembang apalagi saat pembelajaran daring. Hal tersebut didukung dengan hasil penelitian yang dilakukan oleh Kartika Aprilia Penelitian tersebut menyatakan bahwa siswa terhadap soal kemampuan pemecahan masalah matematika, terdapat $77 \%$ siswa yang sudah dapat menyelesaikan soal kemampuan pemecahan masalah matematika dengan baik walaupun pembelajarannya dilaksanakan secara daring (online) dan $23 \%$ siswa lainnya masih merasa kesulitan untuk menyelesaikan soal kemampuan pemecahan masalah dikarenakan tidak bisa bertanya ataupun meminta bantuan kepada teman secara langsung(Aprilia et al., 2020).

Salah satu sekolah yang menerapkan pembelajaran daring di masa darurat COVID 19 adalah SD Negeri Kemlagi. Hasil wawancara yang dilakukan dengan salah satu guru di SDN Kemlagi bahwa dikondisi saat pandemi COVID 19, pelaksanaan pembelajaran daring dimulai sejak tanggal 13 Maret 2020 hingga saat ini. Pembelajaran daring yang dilaksanakan mencakup seluruh mata pelajaran yang diajarkan di sekolah, termasuk pembelajaran matematika. Dalam hal ini keadaan yang memaksa siswa dan guru diharuskan belajar jarak jauh. Dalam keaadaan tersebut guru matematika di SDN Kemlagi merasa mengalami kesulitan dalam menyampaikan materi matematika dan siswa kurang bersemangat saat pembelajaran daring. Dengan adanya kesulitan tersebut siswa kurang memahami materi yang telah disampaiakan oleh guru. Pada kelas tinggi salah kelas V di SDN Kemlagi hampir semua siswa kesulitan belajar dalam memahami materi matematika oleh karena itu perlu mengetahui adanya faktor kesulitan belajar matematika yang dialami siswa kelas V di SDN Kemlagi pada saat pembelajaran daring. Menurut Krisdianto mengungkapkan bahwa kesulitan belajar matematika siswa dikarenakan siswa tidak antusias dalam mengikuti pembelajaran daring pada mata pelajaran matematika dan lebih suka melakukan pembelajaran langsung. Selain itu, koneksi internet yang dimiliki siswa kurang mendukung selama proses pembelajaran daring matematika berlangsung (Hadiprasetyo et al., 2020).

Berdasarkan paparan diatas, maka permasalahan yang dibahas dalam penelitian ini adalah analisis kesulitan belajar dan faktor yang menyebabkan kesulitan belajar matetika secara daring. Maka tujuan dari penelitian ini adalah untuk menganalisis kesulitan beajar matematika dan faktor yang menyebabkan kesulitan belajar matematika secara daring bagi kelas V di SD Negeri Kemlagi Mojokerto.

\section{METODE PENELITIAN}

Jenis penelitian yang digunakan yakni penelitian deskriptif kualitatif. Penelitian kualitatif adalah penelitian yang temuannya tidak didapatkan dari tahap kuantifikasi yang berupa angka, perhitungan, maupun statistic (Hermawan, 2019). Penelitian ini memiliki pandangan penelitian yang induktif, berfokus pada pemaknaan individu dan menyelesaikan kompleksitas masalah. Laporan penelitian akhir memiliki struktur atau kerangka kerja yang fleksibel (Karunia Eka Lestari \& Mokhammad Ridan Yudhanegara, 2017). Penelitian dengan menggunakan metode ini bertujuan untuk menggambarkan kondisi yang terjadi saat penelitian ini berlangsung. Penelitian ini ditulis untuk menganalisis kesulitan belajar matematika dan faktor yang menyebabkan kesulitan belajar matematika siswa kelas V secara daring. Data yang digunakan yakni data primer. Data primer dilakukan secarang langsung oleh peneliti. Subjek dalam penelitian ini adalah 5 orang siswa kelas V yang diambil di SDN Kemlagi Mojokerto. Teknik pengumpulan data yang digunakan adalah wawancara dan dokumentasi, Wawancara dilakukan dengan 5 siswa, guru kelas V dan orang tua siswa.

\section{HASIL DAN PEMBAHASAN}

\section{Kesulitan Belajar}

Kesulitan belajar matematika secara daring siswa kelas V di SDN Kemlagi Mojokerto hampir semua mengalami kesulitan belajar saat memahami materi yang disampikan oleh guru saat daring. Siswa kesulitan 
3161 Analisis Kesulitan Belajar Matematika Secara Daring Bagi Siswa Sekolah Dasar - Zuraida Nisaul Alfiyah, Sri Hartatik, Nafiah, Sunanto

DOI: https://doi.org/10.31004/basicedu.v5i5.1297

saat guru mengirimkan video dengan rumus yang panjang yang membuat siswa tersebut menjadi bingung dan kesulitan. Hal ini dapat dipaparkan oleh narasumber utama yakni siswa kelas V dibawah ini:

...." tidak seberapa mengalami kesulitan, ada kesulitan karena tidak paham materi yang disampaikan oleh guru "(Sb01).

....” Tidak terlalu hanya saja kalau ada rumusnya panjang yang membingungkan saya biasanya bertanya kepada guru "(Sb02).

....'Iya karena tidak mengerti materi yang disampaikan oleh guru dan tidak terlalu memahami soal yang diberikan oleh guru, kadang ada materi matematika yang tidak pakai video cuma materi aja, masukin rumusnya terkadang agak bingung"(Sb03).

...." Iya karena kurang memahami materi jika tidak dijelaskan oleh guru secara langsung, Kadang lupa rumusnya yang panjang,"(Sb04).

...." Ada karena belum paham materi yang disampaikan oleh guru"(Sb05).

Sinyal dan kuota internet yang kurang mendukung proses pembelajaran seperti jaringan internet tidak stabil yang mengganggu belajar siswa. Seperti yang disampaikan siswa kelas V:

...."Sinyalnya buruk saat lampu mati lebih mudah dijelaskan guru secara langsung" (Sb04).

....'Tidak ada kuota internet, jaringan tidak ada, handphone kadang dipakai bergantian dan tidak ada yang membantu saya belajar" (Sb05).

Saat guru menyampaikan materi matematika hanya menggunakan aplikasi whatsapp dan hanya mengirimkan materi dengan video saja. Adanya kendala handphone gabung dengan orang tua dan tidak mempunyai kuota internet dan jaringan yang buruk sehingga siswa kesulitan dalam belajar matematika. Hal ini yang disampaikan oleh narasumber ke 2 yakni wali guru kelas Vdi SDN Kemlagi:

..."Terkadang mereka mengalami kesulitan karena mereka terbiasa belajar face to face atau tatap muka jadi saya kasih video melalui WA kemudian baru saya kasih soal. Dari hasil tugas yang saya berikan kemudian meminta foto hasil tersebut dan siswa juga kurang paham dengan materi yang saya berikan. Mungkin ada beberapa siswa selama pembelajaran daring ini, tidak semua siswa dapat memahami konsep matematika. Siswa tidak mempunyai kuota dan tidak bisa mengerjakan soal yang saya berikan karena kendala di kuotanya kemudian harus mengulang-ulang materi yang dibahas."(WK)

Hal tersebut juga disampaikan oleh para orang tua siswa mengatakan bahwa siswa kesulitan memahami rumus yang panjang, materi tidak dijelaskan langsung oleh gurunya seperti tatap muka dan kendalanya yakni jaringan internet dan kuota.

....."Kadang-kadang kalau rumusnya kurang jelas ya mengalami kesulitan”(WM01).

....."Kadang-kadang karena lupa dengan rumus dan materinya"(WM05).

....."Iya karena kan matematika harus dijelaskan secara detail kalau daring itu sulit memahami materi dan harus dilihat berulang-ulang kalau melihat video yang dikirim oleh guru"(WM04).

...."Iya karena tidak dapat tatap muka sama gurunya jadi tidak bisa mengerjakan soal"(WM03).

Kesulitan belajar siswa kelas V yakni tidak memahami materi matematika dengan menggunakan rumus yang panjang yang membuat mereka merasa bingung saat daring, siswa lebih mudah memahami materi jika dijelaskan langsung oleh guru. Adanya gangguan jaringan dan kuota internet buruk sehingga menyebabkan siswa kesulitan dalam memahami materi matematika. Hasil penelitian ini tidak jauh berbeda dengan penelitian Dosmika Ria Simanjuntak dkk, terdapat siswa yang merasa tidak senang dengan adanya pembelajaran daring, jika sudah tidak merasa senang maka siswa akan malas mengikuti pembelajaran, kuota internet dan jaringan internet yang tidak memadai dan siswa merasa kurang memahami materi pembelajaran jika dijelaskan guru secara daring(Simanjuntak et al., 2020). 
3162 Analisis Kesulitan Belajar Matematika Secara Daring Bagi Siswa Sekolah Dasar - Zuraida Nisaul Alfiyah, Sri Hartatik, Nafiah, Sunanto

DOI: https://doi.org/10.31004/basicedu.v5i5.1297

\section{Faktor Yang Menyebabkan Kesulitan Belajar}

Faktor yang menyebabkan siswa kesulitan belajar matematika yakni terdapat faktor internal dan faktor eksternal. Dalam penelitian ini peneliti hanya membatasi 3 aspek faktor internal yakni motivasi, minat dan konsentrasi belajar dan juga Faktor eksternal yakni lingkungan keluarga.

\section{Motivasi}

Siswa kelas V motivasi belajar matematika masih rendah karena terdapat siswa yang masih malas mengerjakan tugas dan tidak bisa mengerjakan soal yang sulit. Hal tersebut didukung oleh pernyataan pada saat wawancara dari siswa saat mengumpulkan tugas sebagai berikut:

....’Tepat waktu tapi terkadang telat karena sulit mengerjakan tugas yang susah"(Sb02).

...."Tidak tepat waktu karena saya malas mengerjakan "(Sb03).

....’'Iya namun pernah 2 kali besoknya baru dikumpulkan karena saya belum punya handphone sendiri, waktu itu mama tidak dirumah handphonennya dibawa mama. "(Sb04).

...”Tugas selalu dikumpulkan tepat waktu"(Sb05).

Pada narasumber kedua yakni guru kelas $\mathrm{V}$ bahwa motivasi siswa cukup baik. Namun, siswa tidak mengerjakan tepat waktu dikarenakan tidak memiliki hanphone sendiri, hanphone nya dipakai orang tua kerja. Hal tersebut dikatan oleh wali kelas V, yakni:

...."anak-anak antusias pada pembelajaran matematika karena saya memberikan video animasi sehingga siswa tertarik dan memotivasi mereka untuk memahami materi pada video itu. Ada beberapa siswa yang tidak mengerjakan tugas yang pertama selain kuota, hanphone juga dipegang oleh kakaknya sehingga tidak mengerjakan tugas kalau siswa yang megang hanphone sediri sejauh ini masih mengerjakan tugas"(WK).

Narasumber ketiga yakni Wali murid siswa kelas V memberikan motivasi pada anaknya dengan cara mendukung belajar anak saat daring meskipun mengalami kesulitan saat belajar. Hal tersebut didukung oleh pernyataan pada saat wawancara sebagai berikut:

.....”Iya dikasih semangat, ditungguin saat belajar, diajarain kadang anak malas orang tua harus dikasih semangat"(WM01).

...."Semangat memberikan motivasi kepada anak saya”(WM02).

...."Semangat walaupun banyak kesulitan "(WM03).

...."Selalu saya perhatikan saat mendapat tugas "(WM04).

....”Medukung belajarnya"(WM05).

Motivasi belajar matematika siswa kelas $\mathrm{V}$ masih kurang dilihat dari siswa yang masih malas mengerjakan tugas, ada beberapa siswa yang juga mengalami kendala handphone yang bergantian dengan orang tua namun dalam hal ini orang tua selalu memberikan motivasi dan mendukung belajar pada anak mereka sehingga mereka selalu mengikuti pembelajaran daring. Motivasi belajar harus dapat ditanamkan dalam diri siswa itu sendiri Jadi, dapat disimpulkan bahwa motivasi belajar siswa yang masih kurang dapat menjadi faktor dari kesulitan belajar.

Minat

Minat belajar siswa kelas V pada pembelajaran matematika secara daring masih rendah. Siswa tidak menyukai pembelajaran daring lebih senang dengan pembelajaran secara langsung. Hal tersebut terlihat dari wawancara dengan siswa sebagai berikut:

....”Tidak suka karena tidak paham materi yang disampaikan oleh guru"(Sb01).

...."Biasa aja"(Sb02).

Minat belajar matematika siswa kelas $\mathrm{V}$ masih kurang karena siswa lebih senang belajar secara langsung, hal tersebut telah disampaikan oleh wali kelas $\mathrm{V}$ yakni:

....."Bervariasi ada yang senang dengan matematika kalau ada yang tidak suka dia tidak mengerjakan, kalau yang rajin-rajin biasanya pasti mengerjakan" (WK). 
3163 Analisis Kesulitan Belajar Matematika Secara Daring Bagi Siswa Sekolah Dasar - Zuraida Nisaul Alfiyah, Sri Hartatik, Nafiah, Sunanto

DOI: https://doi.org/10.31004/basicedu.v5i5.1297

Minat belajar berdasarkan wawancara dengan orang tua siswa kelas V pada pembelajaran matematika masih ada yang kurang senang pembelajaran matematika secara daring. Hal tersebut terlihat dari wawancara dengan 5 orang tua siswa sebagai berikut:

....’Tidak senang rumusnya sulit ya kadang bingung jadi kurang memahami materi”(WM01)

....'Kurang senang tidak seperti tatap muka"(WM02)

Minat belajar siswa masih rendah karena ada beberapa siswa yang tidak menyukai pembelajaran matematika secara daring. Hal yang membuat tidak disukai yakni siswa tersebut tidak memahami materi matematika yang dijelaskan oleh guru secara daring lebih senang jika dijelaskan oleh gurunya secara langsung atau pembelajaran tatap muka. Dengan demikian, minat belajar siswa yang kurang menjadi faktor kesulitan dalam pembelajaran matematika secara daring.

\section{Konsentrasi Belajar}

Konsentrasi belajar siswa pada pembelajaran matematika masih kurang. Siswa bosan belajar daring yang materinya hanya melalui video saja. Hal tersebut dilihat dari wawancara dengan siswa sebagai berikut:

....'Iya bosan karena tidak bisa bertemu dengan guru"(Sb01).

....”Iya karena kadang tidak ada animasi lain selain materi itu saja, jika bertemu dengan teman lebih asik"(Sb02).

Konsentrasi beajar siswa saat pembelajaran daring masih kurang efektif. Hal ini dapat dilihat dari siswa yang mengerjakan dan mengirimkan tugas tidak tepat waktu. Seperti yang disampaikan oleh guru wali kelas V, yakni:

...."Siswa berkonsentrasi, namun tidak pada satu waktu itu karena HP-nya gantian dengan kakaknya atau orang tuanya sehingga mereka baru mengerjakan tugas saat malam hari, saya tidak membatasi untuk siswa yang mau mengumpulkan tugasnya"(WK).

Siswa mengalami kendala yakni terganggu oleh sinyal yang membuat siswa kurang berkonsentrasi belajarnya. Hal tersebut dilihat dari wawancara dengan orang tua siswa sebagai berikut :

....'Kurang berkonsentrasi konsentrasi, karena terganggu oleh sinyal"(WM01).

Siswa terkadang kurang berkonsentrasi dengan baik karena beberapa siswa bosan dengan belajar matematika secara daring. Terdapat juga kendala lainnya yakni siswa tersebut tidak memiliki handphone sendiri sehingga mereka harus mengerjakan tugas dimalam hari dan waktu mengumpulkan tugas juga tidak tepat pada hari itu juga dan sinyal yang membuat siswa terganggu saat belajar matematika secara daring. Pada pembelajaran matematika membutuhkan konsentrasi yang tinggi untuk memahami materi dan soal yang diberikan oleh guru walaupun saat daring. Jadi, dapat disimpulkan bahwa konsentrasi belajar siswa menjadi faktor kesulitan belajar matematika secara daring.

\section{Lingkungan Keluarga}

Lingkungan keluarga dapat mempengaruhi proses belajar siswa dirumah. Dalam wawancara berikut ini faktor keluarga yang berfokus pada cara orang tua mendidik dan mendukung belajar anak. Orang tua masih memarahi anaknya jika tidak mengerjakan tugas dan tidak mendampingi anaknya saat belajar. Hal ini disampaikan oleh siswa kelas V sebagai berikut:

...."Iya dimarahi, tidak didampingi karena orang tua saya karena merawat adek saya"(Sb01).

...."Marah, dinasehati belajarnya ditingkatkan lagi”(Sb02).

...."Membantu belajar dan membantu mengerjakan tugas, Iya selalu didampingi oleh orang tua(Sb03).

....'Kadang-kadang kalau ada yang tidak bisa biasanya diajari oleh orang tua"(Sb05).

Biasanya, dalam lingkungan keluarga apalagi saat pembelajaran daring sangat berpengaruh pada proses belajar siswa. Guru kelas V menyampaiakan bahwa pada saat pembelajaran daring ini hampir semua orang tua mendukung karena sudah hampir 1 tahun para orang tua juga berperan penting saat belajar dirumah, kendala yang dihadapi oleh orang tua saat dirumah terdapat orang tua yang berlatar belakangnya tidak berpendidikan 
3164 Analisis Kesulitan Belajar Matematika Secara Daring Bagi Siswa Sekolah Dasar - Zuraida Nisaul Alfiyah, Sri Hartatik, Nafiah, Sunanto

DOI: https://doi.org/10.31004/basicedu.v5i5.1297

tinggi sulit untuk membantu siswa dalam belajar matematika saat daring. Hal tersebut disampaikan oleh wali kelas V sebagai berikut :

...."orang tua mendukung, karena sudah hampir 1 tahun orang tua sudah terbiasa untuk menemani anakanaknya belajar dirumah, ada kendala orang tua yang berlatar belakangnya tidak berpendidikan tinggi jadi sulit untuk membantu anaknya ada yang sudah lupa atau tidak mengerti materi matematika."(WK).

Saat dirumah orang tua selalu mendukung dan mendampingi anaknya saat belajar. hal ini disampaikan oleh Wali Murid kelas V sebagai berikut:

....'Iya setiap hari ditungguin, mengarahkan saat belajar dan membantu mengerjakan sampai selesai"'(WM01).

....”Iya kadang-kadang kalau tidak bisa dikasih tau, kasih semangat, ditungguin saat belajar"(WM02).

....’Iya pelajaran matematika harus didampingi, sebisa saya membantu kalau tidak bisa dikerjakan bersama-sama"(WM03).

....”Iya kalau tidak bisa nanti tanya ke gurunya, tugas harus dikerjakan dan diperhatikan”(WM04).

....."Mendampingi dan mengawasi saat belajar kalau ada materi yang sulit dibantu"(WM05).

Pada aspek lingkungan keluarga orang tua siswa masih banyak yang memarahi anak ketika tidak mengerjakan tugas, ada beberapa siswa yang tidak didampingi oleh orang tuanya saat belajar. Dengan orang tua yang memarahi anaknya dan tidak mendampingi saat belajar siswa tersebut akan mengalami kesulitan dalam proses pembelajaran secara daring. Namun, hampir semua orang tua mendukung proses pembelajaran daring walaupun ada kendala pada latar belakang orang tua yang tidak berpendidikan tinggi jadi sulit untuk membantu anaknya belajar. Dengan demikian orang tua dan guruharus dapat berkomunikasi dengan baik saat siswa mengalami kesulitan agar siswa lebih mudah memahami materi dan tidak akan mengalami kesulitan dalam proses pembelajaran secara daring.

\section{KESIMPULAN}

Kesulitan belajar matematika secara daring kelas V di SDN Kemlagi Mojokerto disebabkan oleh siswa tidak memahami materi matematika dengan menggunakan rumus yang panjang yang membuat mereka merasa bingung saat daring, siswa lebih mudah memahami materi jika dijelaskan langsung oleh guru. Adanya gangguan jaringan dan kuota internet buruk sehingga menyebabkan siswa kesulitan dalam memahami materi mtematika. Ada beberapa kendala yang dihadapi siswa salah satunya jaringan internet dan kuota yang kurang mendukung sehingga belajar mereka sangat terganggu. Faktor-faktor penyebab kesulitan belajar matematika secara daring terdapat 2 faktor yakni faktor internal dan eksternal. Faktor internal meliputi aspek motivasi, minat dan konsentrasi belajar. Motivasi belajar matematika siswa masih rendah, siswa masih ada yang malas mengerjakan tugas. Ada beberapa siswa yang juga mengalami kendala handphone yang bergantian dengan orang tuanya namun dalam hal ini orang tua selalu memberikan motivasi dan mendukung belajar siswa. Minat belajar siswa tergolong masih kurang karena masih ada beberapa siswa yang tidak menyukai pembelajaran matematika secara daring. Konsentrasi belajar siswa terkadang kurang baik karena beberapa siswa bosan dengan belajar matematika secara daring. Terdapat juga kendala lainnya yakni sinyal yang buruk membuat siswa terganggu saat belajar matematika secara daring. Sedangkan untuk faktor eksternal hanya berfokus pada faktor lingkungan keluarga. Lingkungan keluarga dapat menjadi faktor kesulitan belajar siswa dapat dilihat dari cara orang tua mendidik dan medukung belajar siswa. Orang tua masih memarahi anaknya jika anaknya tidak mengerjakan tugas. Orang tua mendukung belajar siswa saat daring namun tidak semua orang tua mendampingi anak saat belajar matematika. 
3165 Analisis Kesulitan Belajar Matematika Secara Daring Bagi Siswa Sekolah Dasar - Zuraida Nisaul Alfiyah, Sri Hartatik, Nafiah, Sunanto

DOI: https://doi.org/10.31004/basicedu.v5i5.1297

\section{DAFTAR PUSTAKA}

Annur, M. F., \& Hermansyah. (2020). Analisis Kesulitan Mahasiswa Pendidikan Matematika Dalam Pembelajaran Daring Pada Masa Pandemi Covid-19. Jurnal Kajian, Pnelitian Dan Pengembangan Kependidikan, 11, 195-201.

Annurwanda, P., \& Friantini, R. N. (2019). Efektivitas Penerapan Metode Round Table Dan Ekspositori Terhadap Prestasi Belajar Matematika Ditinjau Dari Kemampuan Awal. Riemann: Research Of Mathematics And Mathematics Education, 1(1), 1-13. Https://Doi.Org/10.38114/Riemann.V1i1.19

Aprilia, K., Nindiasari, H., \& Setiani, Y. (2020). Analisis Kemampuan. 10(10).

Asriyanti, F. D., \& Purwati, I. S. (2020). Hasil Belajar Matematika Siswa Kelas V Sekolah Dasar. 29(1), 7987.

Baety, D. N., \& Munandar, D. R. (2021). Analisis Efektifitas Pembelajaran Daring Dalam Menghadapi Wabah Pandemi Covid-19. Edukatif: Jurnal Ilmu Pendidikan, 3(3), 880-889.

Bilfaqih, Y. (2012). Esensi Pengembangan Pembelajaran Daring. Deepublish.

Bilfaqih, Y. (2015). Esensi Penyusunan Materi Pembelajaran Daring. Deepublish.

Dewi, W. A. F. (2020). Dampak Covid-19 Terhadap Implementasi Pembelajaran Daring Di Sekolah Dasar. Edukatif: Jurnal Ilmu Pendidikan, 2(1), 55-61. Https://Doi.Org/10.31004/Edukatif.V2i1.89

Fauzy, A., \& Nurfauziah, P. (2021). Kesulitan Pembelajaran Daring Matematika Pada Masa Pandemi Covid19 Di Smp Muslimin Cililin. Jurnal Cendekia: Jurnal Pendidikan Matematika, 5(1), 551-561. Https://Doi.Org/10.31004/Cendekia.V5i1.514

Fitriyani, Y., Fauzi, I., \& Sari, M. Z. (2020). Motivasi Belajar Mahasiswa Pada Pembelajaran Daring Selama Pandemik Covid-19. Profesi Pendidikan Dasar, 7(1), 121-132. Https://Doi.Org/10.23917/Ppd.V7i1.10973

Hadiprasetyo, K., Exacta, A. P., \& Maharani, A. (2020). Matematika Dengan Pembelajaran Dalam Jaringan ( Daring ) Selama Masa Darurat Covid-19 Pada Siswa Kelas Viii Smp Negeri 2 Ngadirojo Tahun Ajaran 2019/2020. Vi, 6-12.

Hermawan, I. (2019). Metodologi Penelitian Pendidikan (Kualitatif, Kuantitatif Dan Mixed Methode). Hidayatul Quran.

Jamaris, M. (2014). Kesulitan Belajar: Perspektif, Asesmen, Dan Penanggulangannya Bagi Anak Usia Dini Dan Usia Sekolah (Bogor). Ghalia Indonesia.

Karunia Eka Lestari \& Mokhammad Ridan Yudhanegara. (2017). Penelitian Pendidikan Matematika.

Mufarizuddin. (2018). Analisis Kesulitan Pembelajaran Matematika Siswa Kelas V Sd Negeri 012 Bangkinang Kota. Journal On Education, 1(1), 40-47.

Rini, C. P., Hartantri, S. D., \& Yuliani, S. (2020). Siswa Kelas V Sd Negeri Taman Cibodas Kecamatan Periuk Kota Tangerang. 2(1), 11-20.

Simanjuntak, D. R., Ritonga, M. N., \& Harahap, M. S. (2020). Analisis Kesulitan Belajar Siswa Melaksanakan Pembelajaran Secara Daring Selama Masa Pandemi Covid-19. Mathematic Education Journal)Mathedu, 3(3), 142-146. Http://Journal.Ipts.Ac.Id/Index.Php/

Sintema, E. J. (2020). Effect Of Covid-19 On The Performance Of Grade 12 Students: Implications For Stem Education. Eurasia Journal Of Mathematics, Science And Technology Education, 16(7), 1-6. Https://Doi.Org/10.29333/Ejmste/7893

Susilo, A., Rumende, C. M., Pitoyo, C. W., Santoso, W. D., Yulianti, M., Herikurniawan, H., Sinto, R., Singh, G., Nainggolan, L., Nelwan, E. J., Chen, L. K., Widhani, A., Wijaya, E., Wicaksana, B., Maksum, M., Annisa, F., Jasirwan, C. O. M., \& Yunihastuti, E. (2020). Coronavirus Disease 2019: Tinjauan Literatur Terkini. Jurnal Penyakit Dalam Indonesia, 7(1), 45. Https://Doi.Org/10.7454/Jpdi.V7i1.415 
3166 Analisis Kesulitan Belajar Matematika Secara Daring Bagi Siswa Sekolah Dasar - Zuraida Nisaul Alfiyah, Sri Hartatik, Nafiah, Sunanto

DOI: https://doi.org/10.31004/basicedu.v5i5.1297

Suwarto, 2018. (2018). Analisis Kesulitan Belajar Operasi Hitung Pada Siswa Kelas Satu Sekolah Dasar Mosharafa : Jurnal Pendidikan Matematika Mosharafa: Jurnal Pendidikan Matematika. 7(2), 285-294.

Waskitoningtyas, R. S. (2016). Analisis Kesulitan Belajar Matematika Siswa Kelas V Sekolah Dasar Kota Balikpapan Pada Materi Satuan Waktu Tahun Ajaran 2015/2016. Jipm (Jurnal Ilmiah Pendidikan Matematika), 5(1), 24. Https://Doi.Org/10.25273/Jipm.V5i1.852

Yusmin, E. (2017). Kesulitan Belajar Siswapada Pelajaran Matematika (Rangkuman Dengan Pendekatan Meta-Ethnography). Jurnal Visi Ilmu Pendidikan, 9(1), 2119-2136. Https://Doi.Org/10.26418/Jvip.V9i1.24806 